\title{
Application Of Help Service And Management Of Registration Data Of Patients Klinik Prima Medistra
}

\author{
Noor Latifah ${ }^{1}$, Diana Laily Fithri ${ }^{2}$, Sonia Shekha Anggraini ${ }^{3}$ \\ \{noor.latifah@umk.ac.id ${ }^{1}$, diana.laily@umk.ac.id ${ }^{2}$, soniashekha98@gmail.com ${ }^{3}$ \} \\ Faculty of Engineering, Universitas Muria Kudus, Gondang Manis Bae Kudus, Kudus, 59324, \\ Indonesia $^{123}$
}

\begin{abstract}
The application of services and administration of patient registration data Klinik Prima Medistra is an application designed and built with the aim to assist in improving service and management of patient registration data better. This application is designed by using Context diagram and built by using sublime software, PHP as programming language and Mysql as database. The result of this research is application auxiliary service and manage patient registration data of Klinik Prima Medistra that can improve patient service at Klinik Prima Medistra faster and effective and assist in better managing patient registration data and no double or skid data.
\end{abstract}

Keywords: patient, service, application, data management, registration.

\section{Introduction}

Community service in any field greatly affects the trust and judgment of the community on the institution or company including the health service. Health services involve the role of physician, staff and patient[1]. One of the health services is the registration of patients, patients who have just come to the clinic or other health services are required to register in advance for patient data collection and get queue number. Medical personnel and capable staff provide good service to the consumers of course must be supported by the processing of existing data to facilitate the results of the report[2].

Klinik Prima Medistra is one of the health facilities that serve health services to the community. Health services, especially the registration of patients at Klinik Prima Medistra is still done by inputting data to the computer and not yet using an application or system that helps the registration service and management of patient data this resulted in data slipped or the patient who has been registered and lost medical card listed again so that there is double patient data, as well as medical cards are still written using a pen has not been automatically printed from the system. Registration services that are less rapid can cause the queue of patient registrants longer and so if accompanied by checking the data in advance the time required will be longer. If the service provided is in accordance with the desired, then the visitor will be satisfied, if the opposite happens it will cause loss of visitor interest to seek treatment and this will cause the health center visitors to have negative views on the health center which will result in a decrease in the number of health center visitors[3].

Increasingly sophisticated technology and increasingly widespread Internet usage are able to provide better solutions for data management and can help cope with data slippage and can assist in checking patient data and speeding up the printing of medical cards. From the ICCSET 2018, October 25-26, Kudus, Indonesia

Copyright $(9) 2018$ EAI

DOI 10.4108/eai.24-10-2018.2280523 
background and problems described above then made an application of service aids and manage patient registration data Klinik Prima Medistra.

\subsection{Problem Formulation}

How to analyze and design the application of service aids and manage patient registration data of Klinik Prima Medistra.

\subsection{Limitation Problems}

In this research will be discussed about the management of patient registration data, doctor data input and specialist data management. Information generated by doctors practice schedule information, poly list specialist information, queue number and patient treatment card.

\section{Research Methods}

Research Stages:

a. Data collection In conducting data collection is done by conducting interviews with related parties regarding patient data to be inputted, doctors data, practice schedule data also do literature study related to research.

b. System Planning

This stage is by identifying the problem and then provide an alternative solution application design service aids and manage patient registration data Klinik Prima Medistra.

c. System analysis

At this stage is done on-going system analysis by menggambraknya using FOD to be used as a reference when making system design to be proposed.

d. System design

This stage created a new system design that will be proposed is to create a design using the context diagram.

e. System Implementation

Applying the resulting application that is the application of service aids and manage the registration data of Klinik Prima Medistra patients.

\section{Result and discussion}

\subsection{Flow of Document (FOD)}

Flow of document describes the flow of documents from the running system. FOD in the registration process starts from the patient filling out the registration form with the patient's complete self data. After that, the patient submits the patient's personal data to the admin. 
Then the admin receives the patient's self data and make a medical card and submit the queue number to the patient. Here's FOD from patient registration process.

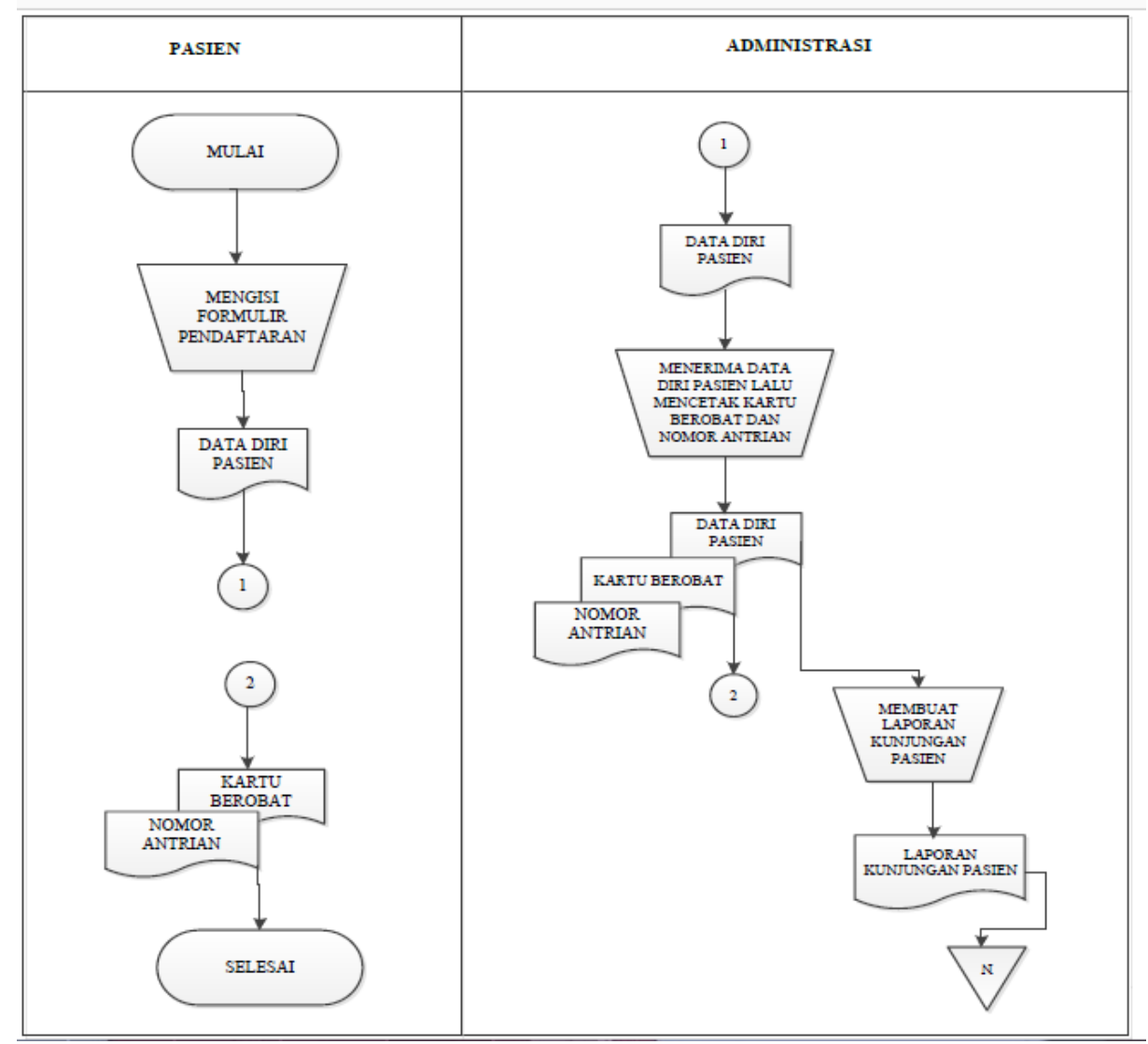

Fig.1. FOD application help service and manage patient registration data Klinik Prima Medistra.

\subsection{System Design}

\subsubsection{Description of functional requirements}

Functional requirements are types of requirements that contain any processes that will be carried out by the system.Functional requirements also contain any information that must exist and be produced by the system[4]. The functional requirements that must exist in the system to be developed are as follows:

1. The system should be able to provide appropriate information about the registration of patients at Klinik Prima Medistra

2. The system should be able to provide information about the list of doctors in Klinik Prima Medistra 
3. The system should be able to provide information about the list of existing specialist poly.

4. The system should be able to provide information about the patient's treatment card so that patients can print medical cards and find out the queue number directly.

Actors within the scope of the system are:

a. Patients performed are:

1. Login System

2. Choosing a targeted doctor

3. Choose a poly specialist in compliance

4. Sign up

5. See information about patient treatment card and queue number

b. Admin

1. Login System

2. Managing doctors who practice data in Klinik Prima Medistra

3. Managing the list of poly specialists in Klinik Prima Medistra

4. Manage patient registration data

5. Provide information about patient treatment card and queue number.

\subsubsection{Context Diagram}

Context diagram is a diagram that consists of a process and describes the scope of a system[5]. In the context diagram below there are two entities involved ie patient and admin. Patient can perform patient data input where the data of nati will be processed in sisten and produce information of patient data which will be accepted by admin. Patient data information received by the admin will be processed back to the system and produced medical treatment card to be given to the patient.

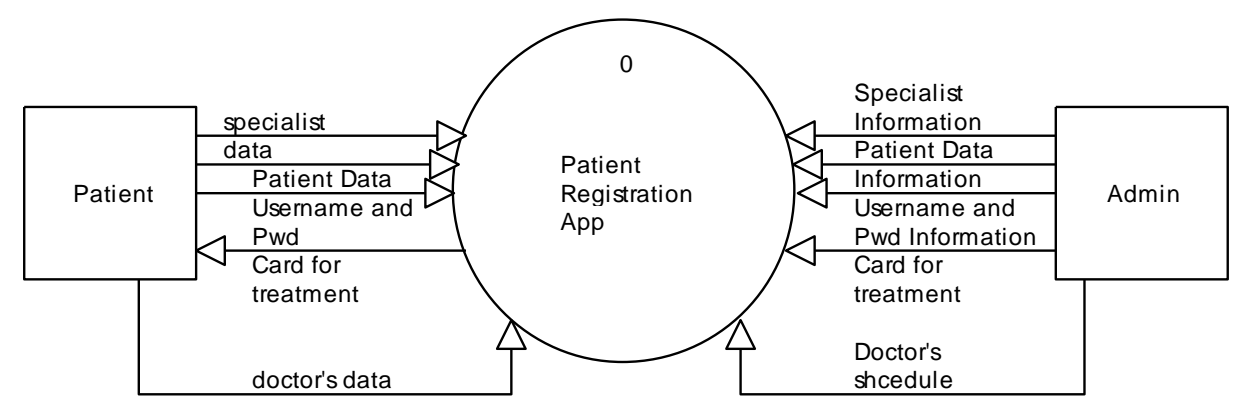

Fig. 2. Context Diagram of service aids application and manage patient registration data of Klinik Prima Medistra.

\subsubsection{DFD Level}

In the DFD level there is a process of admin login process, user login, registration of patient data management, and card printing process. 


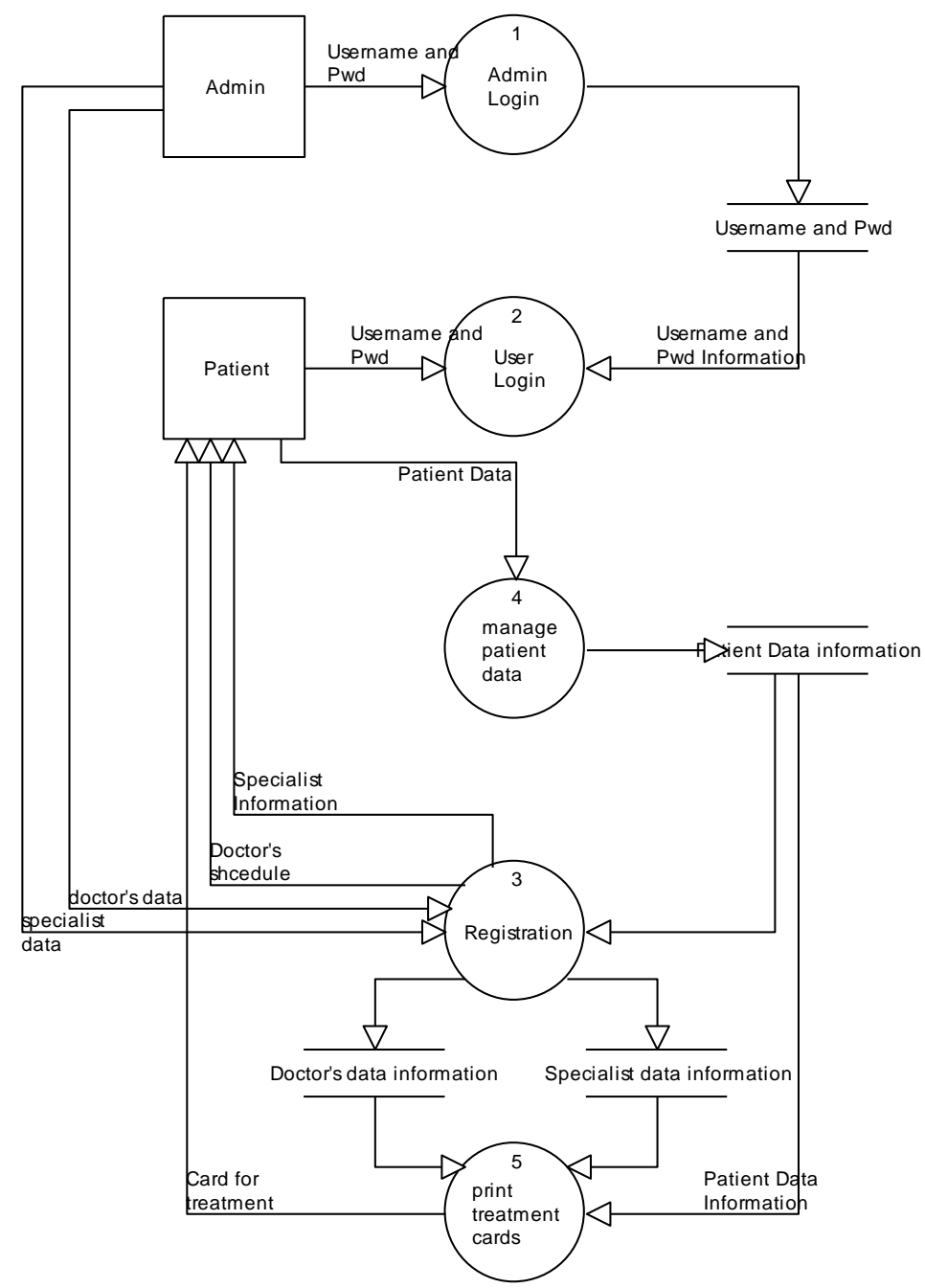

Fig. 3. DFD Level help service application and manage patient registration data of Klinik Prima Medistra.

\subsubsection{Table Relation}

In the application of service aids and manage patient registration data Klinik Prima Medistra there are some table structure that is user table, patient table, specialist table, doctor table, and registration table, for relation between tables can be seen in figure 4 below: 


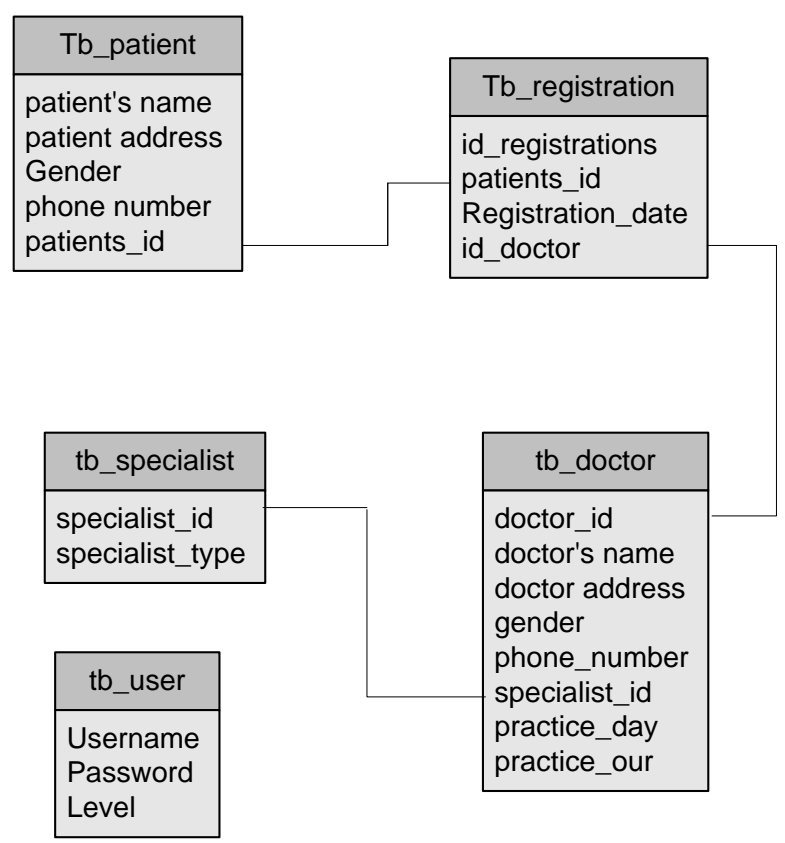

Fig. 4. Relation Table help service applications and manage patient registration data of Klinik Prima Medistra.

\subsection{Implementation System}

1. Patient Registration Form

The image below is used to create a new account for patients to get into the system and be able to enroll when they seek treatment.

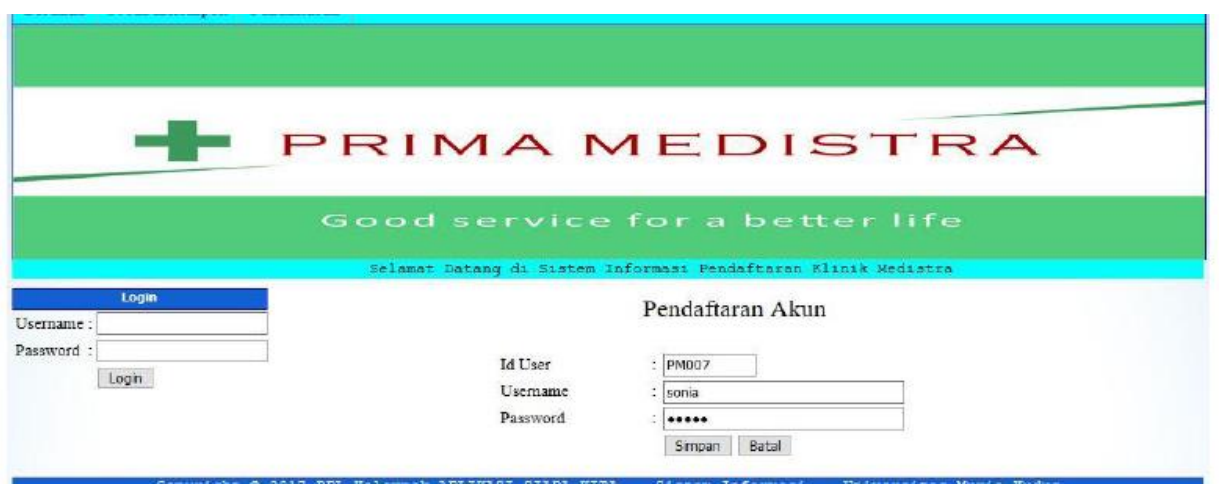

Fig. 5. Registration Form Patient application of auxiliary services and manage patient registration data of Klinik Prima Medistra. 
2. Patient Biodata Form

Form in fig. 6 is used to perform the biodata filling of patients who will register.

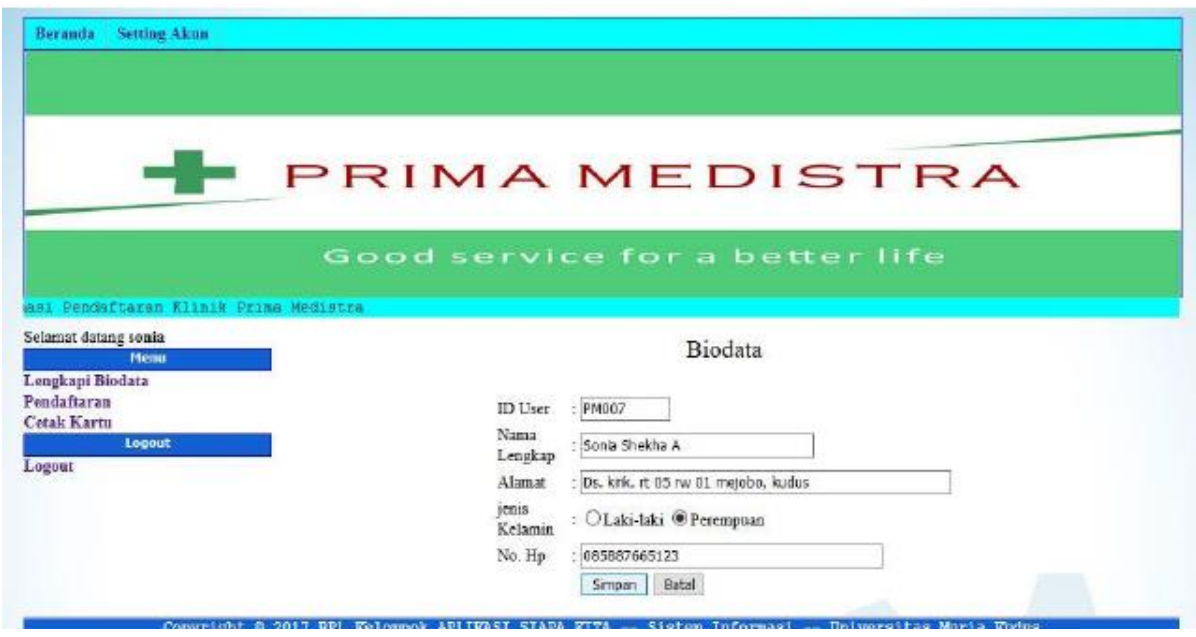

Fig. 6. Form Biodata Patient application aids services and manage patient registration data of Klinik Prima Medistra.

3. Registration Form for treatment

The form in Fig.7 is used to register when the patient wishes to seek treatment

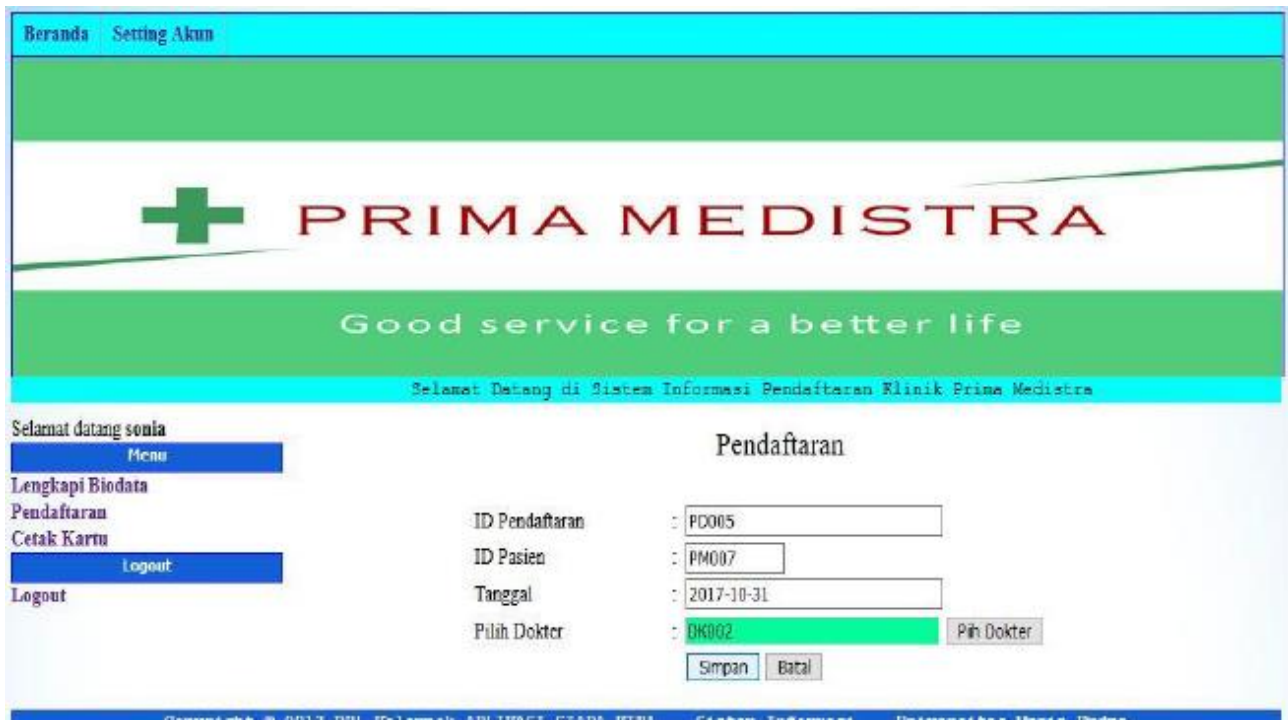

Fig. 7. Patient Registration Form for treatment in auxiliary services application and manage patient registration data of Klinik Prima Medistra. 
4. Admin form manage patient data

Form fig.8. below is used by admin to manage the data of patients who have signed up.

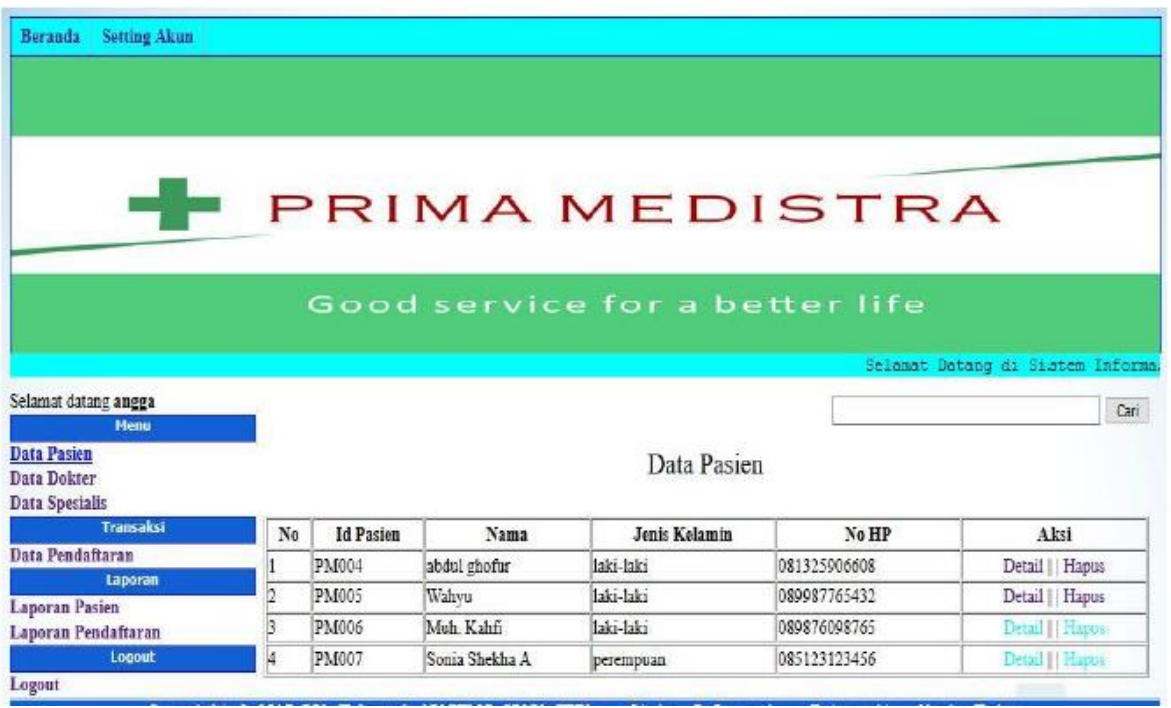

Fig. 8. Admin form managing patient data help service application and manage patient registration data of Klinik Prima Medistra.

5. Input Form Doctor Data

Form Fig.9 is used to input doctor data.

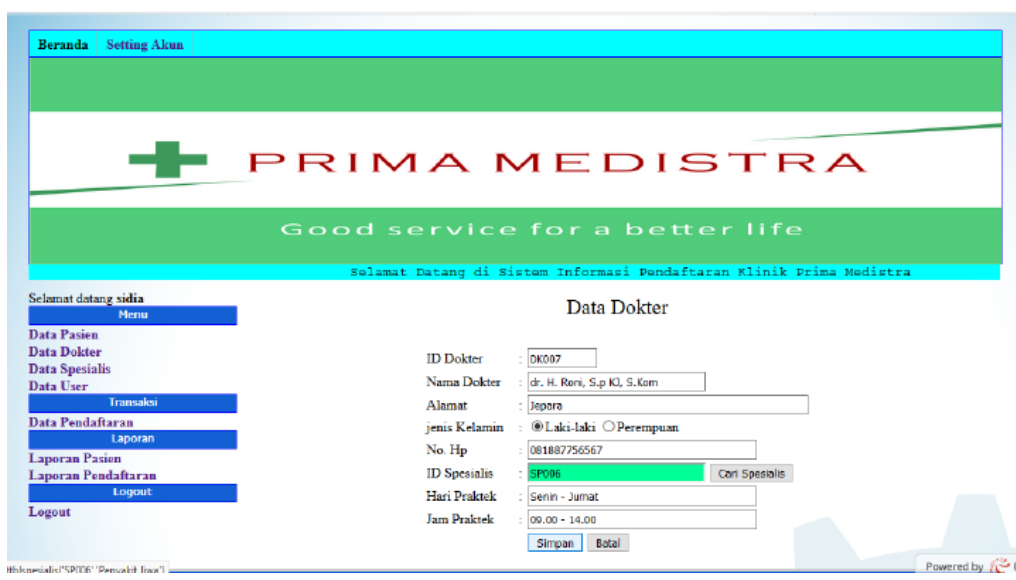

Fig. 9. Admin form manage physician data application help service and manage patient registration data of Klinik Prima Medistra. 


\section{Conclusions And Suggestions}

\subsection{Conclusions}

1. From the results of the design and discussion of the resulting application of service aids and manage patient registration data Klinik Prima Medistra that can help facilitate the work of the admin / officer in charge of managing patient registration.

2. The existence of auxiliary application services and manage patient registration data Klinik Prima Medistra can accelerate the time required to register and manufacture medical card.

3. This system can provide services for patients in the form of registration information, medical practice schedule, list of poly specialist and queue number information and patient treatment card faster than ever before.

\subsection{Suggestions}

The application of services and management of patient registration data of Klinik Prima Medistra can be developed better such as the addition of new features in accordance with ongoing technological developments such as developed into mobile based applications as well as improved security for the system.

\section{References}

[1] Masniah, "An Implementation of Outpatient Online Registration Information System of Mutiara Bunda Hospital," Int. J. Adv. Res. Artif. Intell., vol. 4, pp. 9-16, 2015.

[2] R. Santi and M. R. Arief, "Perancangan Sistem Informasi Pendaftaran Pasien Rawat Inap Di Puskesmas Playen 1,” Teknik Informatika STMIK AMIKOM Yogyakarta, 2016.

[3] Berry Fether and D. Barsasella, "Analisis Sistem Pendaftaran Pasien Rawat Jalan Di Puskesmas Kecamata N Duren Sawit Jakarta Timur 2014,” J. Manaj. Inf. Kesehat. Indones., vol. 3, pp. 43-54.

[4] Hanif Al Fatta, "Analisis dan Perancangan Sistem Informasi." Andi Offset, Yogyakarta, 2009.

[5] Jogiyanto, "Analisis dan Desain Sistem Informasi Pendekatan Teori Terstruktur dan PraktikAplikasi Bisnis.” Andi Offset, Yogyakarta, 2005. 